\title{
Effects of Incubation Conditions on Sex Determination, Hatching Success, and Growth of Hatchling Desert...
}

Article in Herpetological Monographs · January 1994

DOI: $10.2307 / 1467074$

CITATIONS

77

9 authors, including:

\section{Christopher Binckley}

Arcadia University

23 PUBLICATIONS 726 CITATIONS

SEE PROFILE

\section{David C Rostal}

Georgia Southern University

58 PUBLICATIONS $\quad \mathbf{1 , 1 5 9}$ CITATIONS

SEE PROFILE
READS

72

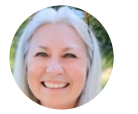

Janice Grumbles

Georgia Southern University

18 PUBLICATIONS 593 CITATIONS

SEE PROFILE

Stanley J. Kemp

University of Baltimore

13 PUBLICATIONS 358 CITATIONS

SEE PROFILE

Some of the authors of this publication are also working on these related projects: 
ction and the Descent of Man. Aldine, llinois.

. B. 1972. The function of breeding in the lizard Sceloporus virgatus. Copeia 364 .

F. 1979. Locomotion. Pp. 435-455. less and H. Morlock (Eds.), Turtles: Pernd Research. Wiley, New York.

. G., JR. 1970. Courtship and combat n Gopherus berlandieri. Bull. Fla. State $-43$.

A. M., AND R. HARDY. 1948. Studies sert tortoise, Gopherus agassizii. Ecol. $8: 145-200$

Accepted: 6 March 1994 Associate Editor: James Spotila

Herpetological Monographs, 8, 1994, 103-116 (C) 1994 by The Herpetologists' League, Inc.

\title{
EFFECTS OF INCUBATION CONDITIONS ON SEX DETERMINATION, HATCHING SUCCESS, AND GROWTH OF HATCHLING DESERT TORTOISES, GOPHERUS AGASSIZII
}

\author{
JAMES R. SPOTILA, ${ }^{1}$ Linda C. Zimmerman, ${ }^{1}$ \\ Christopher A. BinCKLey, ${ }^{1}$ Janice S. Grumbles, ${ }^{1}$ \\ David C. Rostal, ${ }^{2}$ Albert List, Jr., ${ }^{1}$ Eva C. Beyer, ${ }^{1}$ \\ Kelly M. Phillips, ${ }^{3}$ AND Stanley J. KemP ${ }^{1}$ \\ ${ }^{1}$ Department of Bioscience and Biotechnology, Drexel University, \\ Philadelphia, PA 19104, USA \\ ${ }^{2}$ Center for Reproduction of Endangered Species, Zoological Society of San Diego, \\ P.O. Box 551, San Diego, CA 92112, USA \\ ${ }^{3}$ Department of Biological Sciences, University of Nevada Las Vegas, \\ Las Vegas, NV 89154, USA
}

\begin{abstract}
Incubation temperature has a direct effect on sex determination of the desert tortoise. Low temperatures (26.0-30.6 C) produce males and high temperatures (32.8-35.3 C) produce females. Pivotal temperature is approximately $31.8 \mathrm{C}$. Macroscopic and microscopic anatomy of the gonads is similar to that of other turtles. Hatching success and survival is very good between 28.1 and $32.8 \mathrm{C}$ in dry sand $(-5000 \mathrm{kPa})$. Incubation at $35.3 \mathrm{C}$ is lethal for $72 \%$ of the eggs and produces weak hatchlings that die within 45 days. Wet sand $(-5 \mathrm{kPa})$ is lethal for desert tortoise eggs. Hatchling size was dependent upon egg size and incubation condition. Hatchlings from eggs incubated at 32.8 and $35.3 \mathrm{C}$ were significantly smaller than hatchlings from eggs incubated at 28.1 and $30.6 \mathrm{C}$. Hatching mass had no effect on growth rate of hatchlings. Thus, large eggs produced large hatchlings that were larger than their siblings at 120 days of age. Hatchlings from eggs incubated at $30.6 \mathrm{C}$ grew significantly more than hatchlings incubated at 28.1 and $32.8 \mathrm{C}$. Hatchlings incubated at $35.3 \mathrm{C}$ lost mass. Incubation condition did not affect temperature selected in a substrate thermal gradient when hatchlings were tested within one week $(\bar{x}=29.2 \mathrm{C})$ or 40 days of hatching $(\bar{x}=26.6 \mathrm{C})$.

Because of temperature-dependent sex determination and the effect of incubation conditions on hatching success and later growth, management strategies for the desert tortoise should be very conservative. To ensure normal sex ratios of desert tortoises, natural vegetation communities and native soil composition and structure must be preserved or restored. Long term recovery and survival of desert tortoises can only be assured when we have information on pivotal temperatures and nesting ecology for its various populations.
\end{abstract}

Key words: Gopherus agassizii; Eggs; Growth; Hatchlings; Incubation; Temperature-dependent sex determination; Temperature selection; TSD

CURRENT management decisions about the desert tortoise (Gopherus agassizii) are being made without the benefit of a basic understanding of the factors controlling reproduction in this animal (Spotila and Standora, 1986). It is now well known that, whereas most vertebrates have genetically fixed sex determination (GSD), some lizards, most crocodilians and most turtles exhibit temperature-dependent sex determination (TSD), in which the incubation temperature of the eggs determines their sex. Because other environmental factors, such as osmotic stress (Gutzke and Paukstis, 1983) and $\mathrm{O}_{2}$ and $\mathrm{CO}_{2}$ levels (Ackerman, $1981 a, b)$, may also affect sex deter- mination, this phenomenon is also termed environmental sex determination (ESD). TSD/ESD presents particular problems for biologists and administrators who are involved in protecting, managing or mitigating adverse environmental impacts on these species (Spotila and Standora, 1986). For example, artificial incubation of green turtle (Chelonia mydas) eggs produced predominately male hatchlings because of low temperatures and this conservation strategy threatened the survival of sea turtles (Morreale et al., 1982; Spotila et al., 1987). Artificial incubation of Kemp's Ridley turtles (Lepidochelys kempi) also resulted in male biased sex ratios (Wibbels 
et al., 1989). Incubation of leatherback eggs (Dermochelys coriacea) in Malaysia as a management strategy was a failure at least in part because TSD was not considered (Mortimer, 1992). The population there is now essentially extirpated. Additionally, TSD also has conservation ramifications for Cagle's map turtles (Graptemys caglei) because of its restricted distribution (Wibbels et al., 1991b). If TSD occurs in the desert tortoise, this would have important implications for maintaining balanced sex ratios, managing habitat requirements, and ensuring reproductive success of populations of this species.

In freshwater and marine turtles, high temperatures (31.0 $\mathrm{C}$ and above) produce females and low temperatures (24.0-26.0 C) produce males. In addition, several species also show a lower threshold temperature, such that females are produced at temperatures below 20.0-24.0 C (see Bull, 1980, 1983; Ewert et al., 1994; Spotila et al., 1994; Standora and Spotila, 1985; and Vogt and Bull, 1982 for reviews). In general, there is a relatively sharp distinction between those incubation temperatures that produce male turtles and those that produce females. The pivotal or threshold temperature is the temperature producing a one to one sex ratio. There may be a genetic influence on sex determination because both males and females are produced over a broad range of temperatures in some species of turtles (Ewert et al., 1994). In addition, it has been suggested that incubation temperature can affect growth rate, behavior, and temperature selection in alligators (Alligator mississippiensis, Deeming and Ferguson, 1989), snapping turtles (Chelydra serpentina, Miller et al., 1987; Ryan, 1990), and leopard geckos (Eublepharis macularius, Gutzke and Crews, 1988).

The only data available for tortoises are those of Pieau $(1971,1972,1978)$ for Testudo graeca in Europe. The threshold temperature range for this species is 30.0-31.0 C. Thus, we predicted that the upper threshold temperature for the desert tortoise, if TSD occurred in this species, would be above 30.0 C (Spotila and Standora, 1986).
Knowledge about the effects of incubation conditions on sex determination, hatching success, temperature selection, and post-hatching growth of hatchling desert tortoises will be useful in planning conservation efforts such as habitat protection, transplanting of populations, and captive breeding programs. Attempts to manage this species without such information may be counterproductive. The effect of human activities on the suitability of soils for nesting and successful hatching remains unknown. Does grazing affect the temperature profile or water content of the soil and thus of the desert tortoise nest? Does compaction of the soil and removal of vegetation by off-road vehicles alter thermal conductivity and thermal diffusivity of the soil? This might affect heat transfer within soil horizons, soil temperatures, and nest temperatures. If the desert tortoise has genetically fixed sex determination (GSD), there would be less immediate concern about the thermal conditions within tortoise nests as long as they allow normal embryonic development. All of these questions and issues await the answer to the question: What is the mechanism of sex determination in the desert tortoise?

Therefore, the objective of this study was to determine if incubation conditions such as temperature and soil moisture affect sex and hatching success of desert tortoise eggs, and if incubation conditions affect the post-hatching growth and temperature selection of hatchling desert tortoises.

\section{METHODS}

We conducted two incubation experiments. In 1991, we incubated desert tortoise eggs at 26.0 and $33.0 \mathrm{C}$ and 4.0 and $0.4 \%$ soil moisture content $(-5 \mathrm{kPa}$ and $-5000 \mathrm{kPa}$ ) in $500 \mathrm{~g}$ of sand. In 1992 , we incubated eggs at 28.1, 30.6, 32.8, and 35.3 $\mathrm{C}$ and $0.4 \%$ soil moisture content in sand. In all of these experiments, temperatures were measured with $\mathrm{Cu}-\mathrm{Cn}$ thermocouples and a BAT-12 or Wescor T-65 thermocouple meter. Thermocouples were accurate to $0.1 \mathrm{C}$. Soil moisture tension was measured using a pressure plate apparatus and by equilibrating sand over saturated 
about the effects of incuins on sex determination, ss, temperature selection, ling growth of hatchling will be useful in planning forts such as habitat proanting of populations, and ng programs. Attempts to Jecies without such inforcounterproductive. The efactivities on the suitability ing and successful hatching wn. Does grazing affect the ofile or water content of the of the desert tortoise nest? on of the soil and removal by off-road vehicles alter ıctivity and thermal diffujil? This might affect heat 1 soil horizons, soil tempert temperatures. If the desert netically fixed sex determithere would be less immeabout the thermal conditions nests as long as they allow yonic development. All of 3 and issues await the answer : What is the mechanism of tion in the desert tortoise? the objective of this study ine if incubation conditions rature and soil moisture afatching success of desert torif incubation conditions afst-hatching growth and election of hatchling desert

\section{METHODS}

ted two incubation experi1 , we incubated desert tor6.0 and $33.0 \mathrm{C}$ and 4.0 and sture content $(-5 \mathrm{kPa}$ and $500 \mathrm{~g}$ of sand. In 1992, we s at $28.1,30.6,32.8$, and 35.3 il moisture content in sand. experiments, temperatures d with $\mathrm{Cu}-\mathrm{Cn}$ thermocouT-12 or Wescor T-65 therer. Thermocouples were acC. Soil moisture tension was g a pressure plate apparatus brating sand over saturated salt solutions (R. Ackerman, personal communication). All masses were determined using a Sartorius top loading balance to $\pm 0.0005 \mathrm{~g}$. We obtained eggs from nests in the reproduction study and other research pens at the Desert Tortoise Conservation Center (DTCC) within a day or two after deposition or, in 1991, by inducing oviposition of gravid females in the laboratory (Ewert and Legler, 1978). We estimated that these eggs were within three days of deposition. Eggs were half buried in sand in sealed $850 \mathrm{ml}$ tupperware containers. Containers were opened every other day for ventilation and rehydrated to constant mass. We rotated positions of containers in incubators every other day to minimize the effects of any temperature gradients in the environmental chambers. To avoid clutch effects, eggs from each clutch were randomized into the different treatments. Eggs were weighed and measured initially and weighed weekly during incubation. Because of the well known difficulty of maintaining constant water potential in sand (Packard et al., 1987), it is likely that water potential varied from expected values during the course of incubation. Therefore, we refer to sand having high water potential at the beginning of an experiment as "wet" and sand having low water potential as "dry." Eggs were handled periodically to determine viability and those eggs that failed to develop were removed from incubation containers. Containers were maintained in Percival environmental chambers (Boone, Iowa) and while temperatures in the chambers varied $\pm 1.0 \mathrm{C}$, temperatures inside the containers only varied $\pm 0.2 \mathrm{C}$.

After hatching, tortoises were raised in plastic containers $(35 \times 40 \times 15 \mathrm{~cm})$ and fed three times a week. They ate a mixture of carrots, broccoli, spinach, and lettuce that was blended with a pelletized version of an iguana diet developed at the National Zoological Park (Allen et al., 1991, available from Zeigler Bros. Inc., Gardners, PA.), and was provided ad libitum. We weighed $( \pm 0.0005 \mathrm{~g}$ on a Sartorius GMBH, model E 200 B, electronic balance) and measured $( \pm 0.05 \mathrm{~mm}$, carapace length, plastron length, height at third vertebral scute, and greatest width with dial calipers) hatchlings at hatching and once a week thereafter. Containers were washed with water and food dishes were washed with a mixture of bactericidal soap, bleach and hot water three times a week. Hatchlings were washed with water to remove fecal material and dried food from their skin and shell. Containers were kept in a room at $30 \pm 2 \mathrm{C}$. Fluorescent lights (Sylvania/GTE F40/350 BL $40 \mathrm{~W}$ black light and GRO-LUX WS F40/GRO/WS 40 W) were suspended $40 \mathrm{~cm}$ above the containers and maintained on a photoperiod of 12:12 L:D. Tortoises and their containers were examined three times a week for general health, evidence of feeding activity, and presence of feces and urine.

Hatchlings were sexed after 1 yr (1991 animals) or after 2-4 months (1992 animals) by visual inspection of the gonads using laparoscopy (Lumina SL-telescope, $0^{\circ}$ vision angle, $1.9 \mathrm{~mm}$ O.D. $\times 10 \mathrm{~cm}$, with a 150 Watt light source, Karl Storz Endoscopy-America). We made a small incision in the body wall in front of the right rear leg and examined the gonads through the scope. Details of methodology for sexing hatchlings are given in Rostal et al. (1994). Twenty hatchlings were euthanized ( 2 cc of sodium pentabarbital into thoracic cavity). Their sex was verified by macroscopic examination after dissection and staining with Bouin's solution. Then gonads were fixed in Bouin's solution, embedded in paraffin, sectioned at $10 \mu \mathrm{m}$, stained with hematoxylin/eosin, and sex was confirmed by histology (Spotila et al., 1983). Sexing criteria followed Yntema (1976), Morreale et al. (1982), and Wibbels et al. $(1991 a, b)$.

Temperature selection of hatchlings was measured in a substrate thermal gradient as described in Spotila (1972) and Williamson et al. (1989). The gradient contained an aluminum bar at the bottom of an insulated wooden box which was coated with fiberglass resin. The selection chamber measured $153 \times 15 \times 8 \mathrm{~cm}$. We placed 31 thermocouples at $5 \mathrm{~cm}$ intervals along the bar to measure substrate temperature. Except for the extreme ends of the gradient, we maintained a 0.5-1.0 C differ- 
TABLE 1.- Hatchling success, incubation time, and percentage females of desert tortoise eggs incubated under controlled conditions at the DTCC.

\begin{tabular}{|c|c|c|c|c|c|c|}
\hline Year & $\begin{array}{l}\text { Tempera- } \\
\text { ture (C) }\end{array}$ & $\begin{array}{c}\text { Soil } \\
\text { moisture } \\
(\%)\end{array}$ & $n$ & $\begin{array}{c}\text { Incuba- } \\
\text { tion } \\
\text { time } \\
\text { (days) }\end{array}$ & $\underset{(\%)}{\text { Survival }}$ & $\%$ female \\
\hline 1991 & 26.0 & 4.0 & 10 & - & 0 & - \\
\hline 1991 & 26.0 & 0.4 & 10 & 125 & 50 & 0 \\
\hline 1991 & 33.0 & 4.0 & 10 & 73 & 33 & 100 \\
\hline 1991 & 33.0 & 0.4 & 10 & 73 & 90 & 100 \\
\hline 1992 & 28.1 & 0.4 & 29 & 89 & 96 & 0 \\
\hline 1992 & 30.6 & 0.4 & 29 & 72 & 93 & 4 \\
\hline 1992 & 32.8 & 0.4 & 29 & 68 & 93 & 100 \\
\hline 1992 & 35.3 & 0.4 & 28 & 85 & 29 & 100 \\
\hline
\end{tabular}

ence between stations with a range of 5.045.0 C. We placed a $0.6 \mathrm{~cm}$ layer of alfalfa pellets on the bottom of the gradient as substrate for the tortoises. Alfalfa was used so that tortoises would not be harmed if they ate the material. We mixed substrate and added new substrate after each trial to prevent bias in temperature selection due to olfactory cues. Substrate was removed if it became wet or dirty. The temperature gradient was established by cooling one end with ice and heating the other end with a heating element attached to a variable transformer. Both the ice and heater were separated from the operational portion of the gradient by wooden partitions.

Experiments were conducted between 0900 and $1900 \mathrm{~h}$ using hatchlings that were eating normally. In 1991, individual hatchlings were placed into the gradient alone after 40 days of growth. In 1992, hatchlings were placed individually into the gradient within a week of hatching. We placed a 36 gauge thermocouple into the cloaca of each hatchling and took the body temperature after a 6 h equilibration period at the selected temperature. Data were analyzed using analysis of variance (ANOVA), analysis of covariance (ANCOVA) and regression models. We used the Tukey-Kramer post hoc test to clarify differences in means when there was a significant difference by ANOVA or ANCOVA. We followed Sokal and Rohlf (1981) for statistical designs, performed computations with super ANOVA and as-

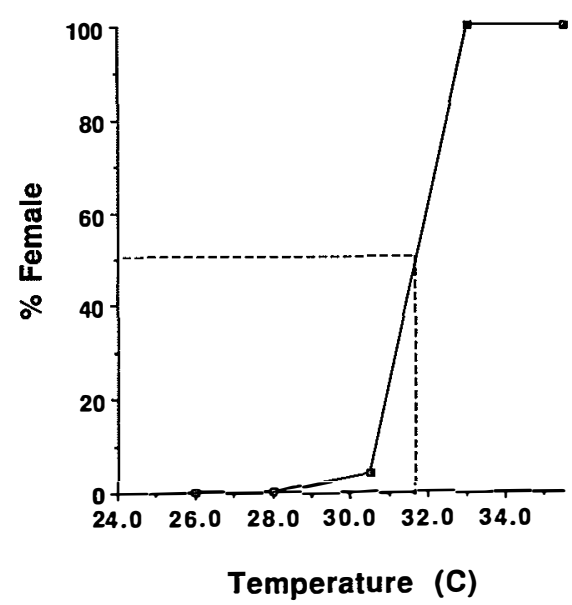

FIG. 1.-Effect of incubation temperature on sex determination in the desert tortoise. Pivotal temperature was approximately $31.8 \mathrm{C}$. Hatching success was excellent between 28.1 and $33.2 \mathrm{C}$ in dry sand.

sumed $P=0.05$ as the level of statistical significance.

\section{RESULTS}

Incubation temperature had a direct effect on sex determination of desert tortoises. Low temperature incubation (26.0, $28.1,30.6 \mathrm{C}$ ) produced male tortoises and high temperature incubation $(32.8,33.0$, and $35.3 \mathrm{C}$ ) produced female tortoises $(\mathrm{Ta}-$ ble 1$)$. In dry sand $(0.4 \%$ soil moisture $)$, survival was very good from $28.1-33.0 \mathrm{C}$, but was only $50 \%$ at 26.0 and $29 \%$ at 35.3 C. Differential mortality during incubation did not appear to affect sex ratios. There was little mortality at intermediate temperatures. At 35.3 C, of the eight dead embryos that were mature enough for us to sex histologically, all were females. The embryos that died at $26.0 \mathrm{C}$ were not old enough to be sexed. From these data, we determined that the pivotal temperature (50\% female) was approximately $31.8 \mathrm{C}$ (Fig. 1). Additional experiments are needed to refine this estimate (see Discussion).

The macroscopic anatomy of the gonads in hatchling desert tortoises was similar to that described for other turtles and was readily recognizable using the miniature laparoscope. The view through the laparoscope is described in Rostal et al. (1994) 

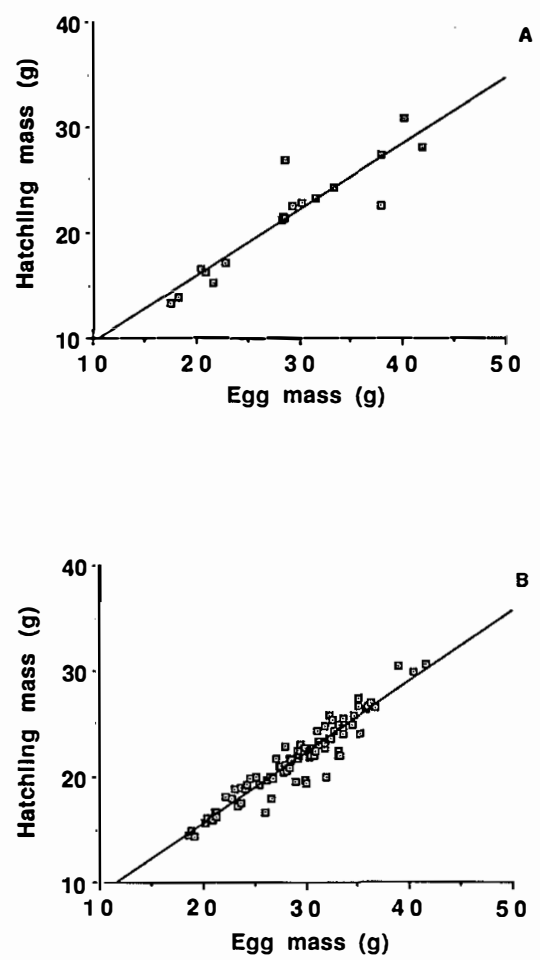

FIG. 4.-Linear relationship of hatchling mass to initial egg mass in the desert tortoise. A) In 1991, the regression equation for the line was $\mathrm{M}_{\mathrm{h}}=0.624 \mathrm{E}+$ $3.383\left(r^{2}=0.851\right)$. B) In 1992, the regression equation for the line was $\mathrm{M}_{\mathrm{h}}=0.67 \mathrm{E}+2.146\left(r^{2}=0.899\right)$. $M_{h}$ is mass at hatching. $E$ is egg mass.

eggs. None of the eggs incubated under cool $(26.0 \mathrm{C})$, wet ( $4.0 \%$ soil moisture) conditions in 1991 hatched. In 1992, incubation time was inversely related to incubation temperature from 28.1 C (89 days) to $32.8 \mathrm{C}$ (68 days)(Table 1 ). Incubation time increased at $35.3 \mathrm{C}$ and survival decreased from $93 \%$ at $32.8 \mathrm{C}$ to $29 \%$. Apparently $35.3 \mathrm{C}$ is too high a temperature for normal development of desert tortoise eggs. Incubation times at $33.0 \mathrm{C}$ in 1991 were extended because oviposition was induced early using oxytocin. Incubation time was extended at both $26.0 \mathrm{C}$ (125 days) and 35.3 C (85 days). Desert tortoise eggs had difficulty incubating at $26.0 \mathrm{C}$ and died in wet sand. At 32.8-33.0 C, hatching success was $90-93 \%$ in dry sand but only $33 \%$ in wet sand. Of the three eggs that survived at $33.0 \mathrm{C}$ in wet sand, two suffered cracks in their shells. We re-
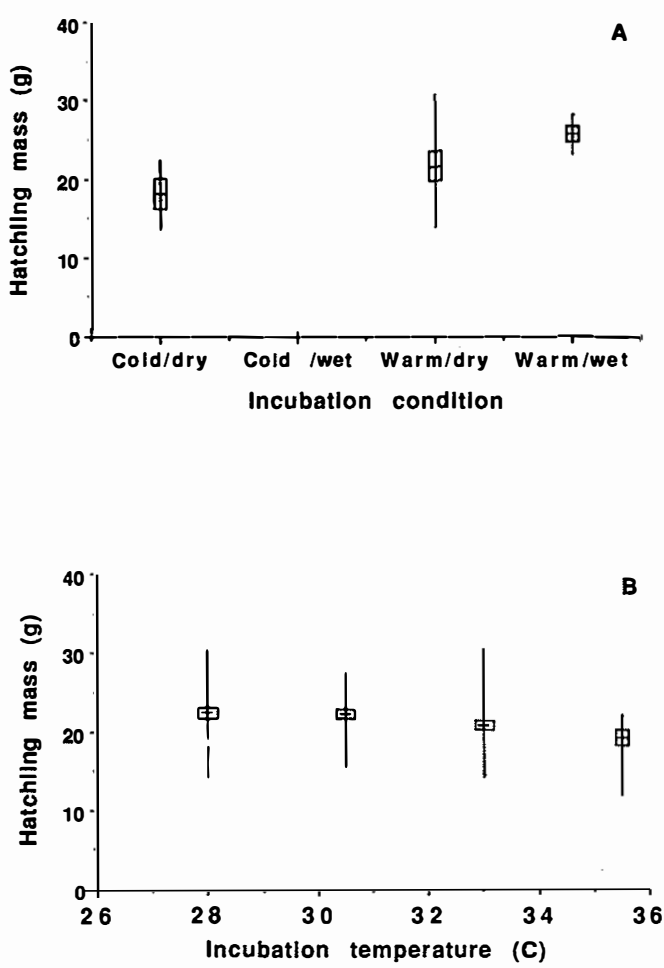

FIG. 5.-Relationship of hatching mass to incubation condition for desert tortoises incubated at the DTCC. A) 1991. Cold/dry is $26.0 \mathrm{C}, 0.4 \%$ soil moisture $(-5000$ $\mathrm{kPa})$; Cold/wet is $26.0 \mathrm{C}, 4.0 \%$ soil moisture $(-5 \mathrm{kPa})$; Warm/dry is $33.0 \mathrm{C}, 0.4 \%$ soil moisture; Warm/wet is $33.0 \mathrm{C}, 4.0 \%$ soil moisture. No hatchlings were produced in the Cold/wet incubation condition. B) 1992. Moisture potential at all temperatures was -5000 $\mathrm{kPa}(0.4 \%$ soil moisture). Horizontal line represents mean, vertical line represents range and open rectangle represents $1 \mathrm{SE}$ on either side of mean.

paired the shells with epoxy glue and reduced the portion of the shell in contact with the sand so that they hatched, but without our intervention these eggs probably would not have survived because their contents would have been exposed to microorganisms.

Hatchling size was dependent on egg size and incubation condition. In both the 1991 and 1992 experiments, a linear regression indicated that hatchling mass was dependent upon initial egg mass (Fig. 4A,B). We then completed an ANCOVA for hatchling mass as a function of incubation condition with egg mass as the covariate. In the 1991 experiment, there was no statistically significant effect of incu- 


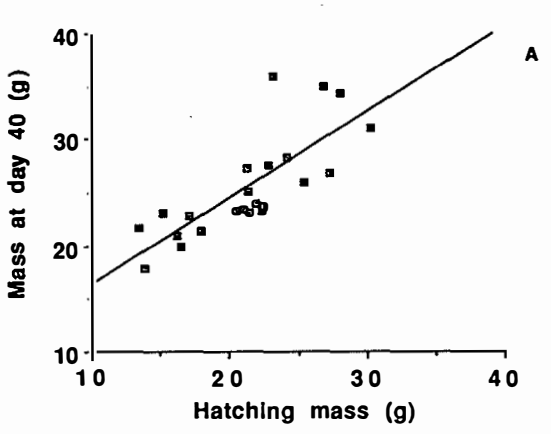

Cold /wet Warm/dry Warm/wet Incubation condition

\begin{tabular}{lcccc}
\hline 8 & 30 & 32 & 34 & 36 \\
Incubation & temperature & (C) &
\end{tabular}

inship of hatching mass to incubation sert tortoises incubated at the DTCC. ry is $26.0 \mathrm{C}, 0.4 \%$ soil moisture $(-5000$ is $26.0 \mathrm{C}, 4.0 \%$ soil moisture $(-5 \mathrm{kPa})$; $3.0 \mathrm{C}, 0.4 \%$ soil moisture; Warm/wet soil moisture. No hatchlings were e Cold/wet incubation condition. B) otential at all temperatures was -5000 moisture). Horizontal line represents line represents range and open rects $1 \mathrm{SE}$ on either side of mean.

hells with epoxy glue and reortion of the shell in contact id so that they hatched, but intervention these eggs probot have survived because their uld have been exposed to mis. size was dependent on egg ibation condition. In both the 92 experiments, a linear recated that hatchling mass was upon initial egg mass (Fig. hen completed an ANCOVA mass as a function of incution with egg mass as the coe 1991 experiment, there was lly significant effect of incu-
TABLE 2.-Mass gain after 40 days of desert tortoise hatchlings incubated at 28.1, 30.6, 32.8 and $35.3 \mathrm{C}$ at the DTCC in 1992. Any two means not connected by the same vertical line are significantly different (Tukey-Kramer post hoc test, $P=0.05$ ).

\begin{tabular}{|c|c|}
\hline $\begin{array}{c}\text { Incubation } \\
\text { temperature (C) }\end{array}$ & $\begin{array}{l}\text { Mass gain } \\
\text { (g) }\end{array}$ \\
\hline 30.6 & 4.64 \\
\hline 28.1 & 2.73 \\
\hline 32.8 & 1.92 \\
\hline 35.3 & -0.31 \\
\hline
\end{tabular}

and $-5000 \mathrm{kPa})$ and $26.0 \mathrm{C}(-5000 \mathrm{kPa})$ in 1991 were similar. There was no significant difference in mass gain between hatchlings from different incubation conditions (one way ANOVA). Sample sizes were too low given the variation in mass gain to detect a difference. Growth curves of hatchlings incubated at 28.1,30.6,32.8, and $35.3 \mathrm{C}$ in 1992 (Fig. 7A,B,C,D) were also similar up to 120 days after hatching, although most of the hatchlings incubated at $35.3 \mathrm{C}$ died before 45 days of age. There was a significant difference in mass gain between the hatchlings incubated at different temperatures (one way ANOVA, $F$ $=10.358, P=0.001, \mathrm{df}=3,82)$. Hatchlings from the $30.6 \mathrm{C}$ incubation grew significantly more than the other hatchlings (Table 2, Tukey-Kramer test, $P=0.05$ ), while hatchlings incubated at $28.1 \mathrm{C}$ grew as much as those incubated at $32.8 \mathrm{C}$, but more than those incubated at $35.3 \mathrm{C}$. The 35.3 C hatchlings actually lost mass.

Incubation condition did not affect the temperature selected by hatchling desert tortoises. There was no significant difference (one way ANOVA) in the selected temperature between hatchlings incubated under different conditions in 1991 when tested after 40 days of growth (Fig. 8). Mean selected temperature was $26.6 \mathrm{C}$. There was no significant difference (one way ANOVA) in selected temperature between hatchlings incubated at different temperatures in 1992 when tested within one week of hatching (Fig. 8B). Mean selected temperature was $29.2 \mathrm{C}$.

\section{DISCUSSION}

The desert tortoise has temperature-dependent sex determination, expressing 

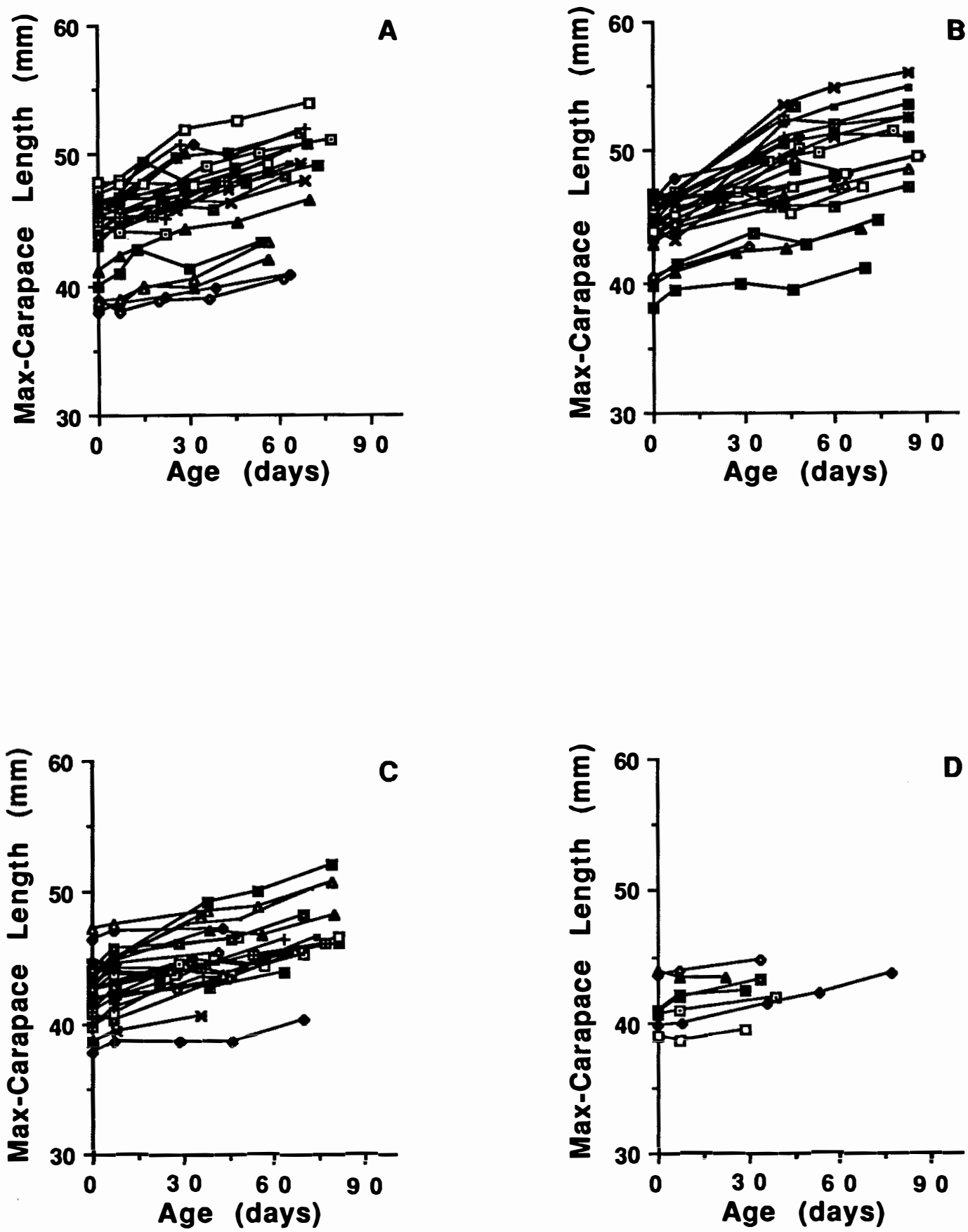

Fig. 7.-Maximum carapace length of hatchling desert tortoises vs. age for eggs incubated at the DTCC in 1992. A) $28.1 \mathrm{C}$; B) $30.6 \mathrm{C}$; C) $32.8 \mathrm{C}$; D) $35.3 \mathrm{C}$. Moisture potential at all temperatures was $-5000 \mathrm{kPa}$ ( $0.4 \%$ soil moisture). 


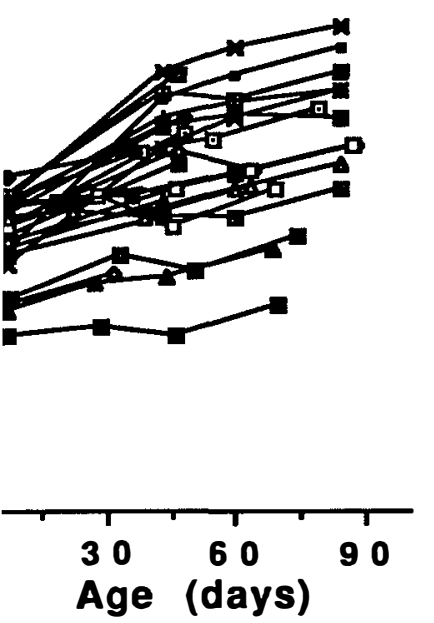

D

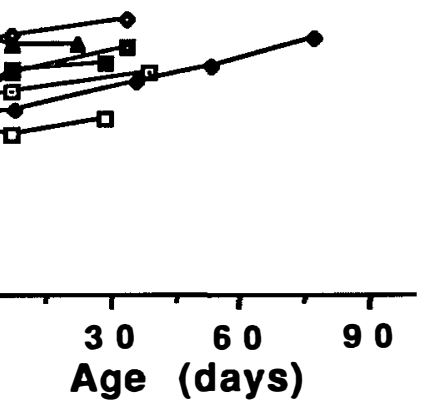

or eggs incubated at the DTCC in all temperatures was $-5000 \mathrm{kPa}$
Pattern 1a of Ewert and Nelson (1991) in which males are produced at low temperatures and females are produced at high temperatures. There is a fairly sharp transition from male to female temperatures with an approximate pivotal temperature of $31.8 \mathrm{C}$. This is higher than the pivotal temperature for the European tortoise $T$. graeca (Pieau, 1971, 1972, 1978), higher than the pivotal temperature for most North American turtles including the box turtles Terrapene carolina $(<30 \mathrm{C})$ and Terrapene ornata $(<29 \mathrm{C})$ (Ewert and Nelson, 1991), and confirms the hypothesis of Spotila and Standora (1986) that the pivotal temperature would be above $30 \mathrm{C}$. Additional research is needed to refine the pivotal temperature because temperatures between 30.6 and 32.8 are untested. Other turtles from the arid western portions of North America also have high pivotal temperatures. The value for Kinosternon flavescens arizonense from the low desert in Sonora is $>31 \mathrm{C}$, and for Clemmys marmorata from seasonally arid south central Oregon is $30 \mathrm{C}$ (Ewert et al., 1994). The three members of the family Pelomedusidae that have been tested also have high pivotal temperatures (Podocnemis expan$s a$-the highest known pivotal temperature, $>32.5 \mathrm{C}$ but $<34.0 \mathrm{C}$ (Alho et al., 1985); Pelomedusa subrufa-32.5 C (Ewert and Nelson, 1991); and Pelusios castaneus - > 30 C but <33 C (Ewert and Nelson, 1991). The first of these species nests in riverine sandbars with extremely high temperatures $(\bar{x}=34.5, \max =38.5$ $\mathrm{C}$, Alho et al., 1985). The natural geographic origin and ecology of the individuals of the other two species tested is unknown. Pivotal temperature appears to vary according to the local thermal and hydric environment to which a turtle population is exposed.

There is considerable intraspecific geographic variation in pivotal temperatures for freshwater turtles (Bull et al., 1982b; Ewert et al., 1994; Vogt and Flores-Villela, 1992). Species in eastern North America nest in relatively cool areas while their populations in the midwestern region nest in more open areas and have higher pivotal
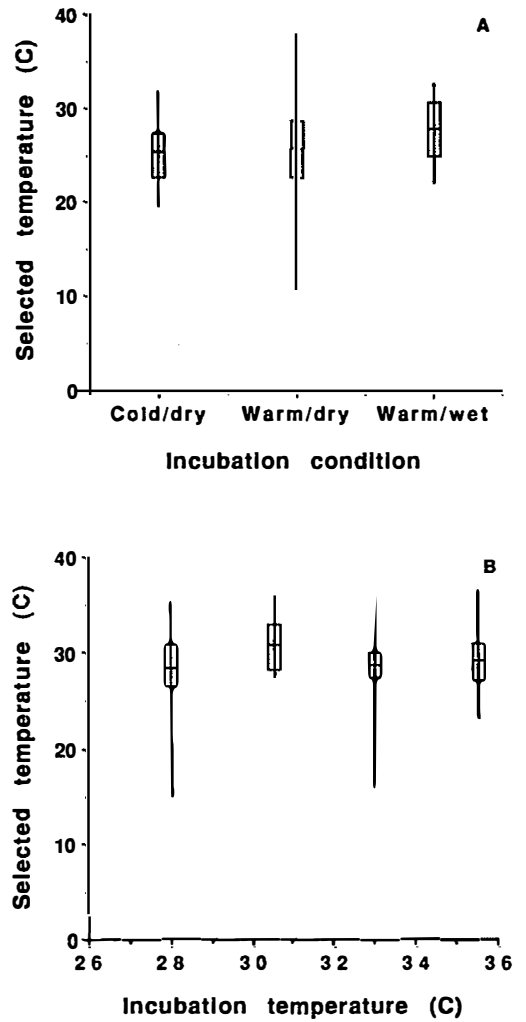

FiG. 8.-Temperatures selected in a substrate thermal gradient by hatchling desert tortoises incubated at the DTCC. A) 1991 at 40 days of age. Cold/dry is $26.0 \mathrm{C}, 0.4 \%$ soil moisture $(-5000 \mathrm{kPa}) ;$ Warm/dry is $33.0,0.4 \%$ soil moisture; Warm/wet is $33.0 \mathrm{C}, 4.0 \%$ soil moisture $(-5 \mathrm{kPa})$. No hatchlings were produced in the Cold/wet incubation condition. There was no significant difference between temperatures selected by hatchlings from different incubation conditions. Overall mean was 26.6 C. B) 1992 within one week of hatching. There were no significant differences between the temperatures selected by the hatchlings from the four incubation temperatures. Overall mean was $29.2 \mathrm{C}$. Mean is represented by the horizontal line, vertical line represents range and open rectangle represents $1 \mathrm{SE}$ on either side of mean.

temperatures (i.e., Chrysemys picta and Graptemys, Ewert et al., 1994). The same ecological trend can be observed in other species in a south to north direction. In both Chelydra serpentina and Trachemys scripta, pivotal temperature increases with latitude and longitude from tropical America to temperate U.S. and Canada (data summarized in Ewert et al., 1994). Nesting sites in the midwest and west tend 
to be warmer than those in the east and the tropics. Therefore, there appears to be selection for higher pivotal temperatures in these areas. Bull et al. (1982a), Janzen and Paukstis (1991) and Janzen (1992) indicated that there is heritable variation for sex ratio in some freshwater turtles. Thus, we would expect that there will be intraspecific variation in pivotal temperature of the desert tortoise. Pivotal temperature may be lower in Sonoran populations in Arizona and Mexico and higher in California populations. There should also be a gradation in pivotal temperature across the genus with Gopherus polyphemus in the east having the lowest pivotal and $\mathrm{Go}$ pherus berlandieri and Gopherus flavomarginatus having intermediate pivotal temperatures, assuming that they have TSD.

Both temperature and substrate moisture content affect hatching success of desert tortoise eggs. High moisture content in sand (4.0\% soil moisture) is lethal at low temperature $(26.0 \mathrm{C}$ ) and would probably have been lethal at $33.0 \mathrm{C}$ if we had not intervened to repair cracked shells and reduce the area of shell in contact with the sand. The rigid shell of the desert tortoise egg appears to take up water from the sand faster than it evaporates water vapor through the portion of the shell exposed to the air. Dry sand ( $0.4 \%$, soil moisture) allows very good hatching success except at 26.0 and $35.3 \mathrm{C}$. These temperatures are generally lethal for embryos of this population of desert tortoise. These results are not unexpected for a desert turtle. The softshell turtle, Apalone (Trionyx) spiniferus, also has a rigid egg shell. Hatching success of eggs of this species is unaffected by incubation at water potentials of -50 to $-850 \mathrm{kPa}$ on vermiculite at $29.0 \mathrm{C}$ (Packard et al., 1981). Eggs of this aquatic species can tolerate much wetter substrates than those of the desert tortoise. Flexibleshelled eggs of turtles typically lose water more rapidly than rigid-shelled eggs and require substrates with higher water potentials (Ackerman, 1992). Female desert tortoises often urinate on their nests before or after nesting. This raises the water potential of the dry desert soil, but whether this is the selective advantage for this be- havior is unknown. As incubation progresses, the soil dries out, but probably retains some moisture due to the presence of a drying front at the edge of the moister soil. It would be interesting to measure the soil moisture content and moisture tension curves for soils in desert tortoise nests to determine the water stress to which the eggs are exposed in nature.

Egg size and incubation condition affect hatchling size of desert tortoises. Large eggs produce large hatchlings. Hatchlings incubated at high temperatures (32.8 and $35.3 \mathrm{C})$ are significantly smaller than hatchlings incubated at low temperatures (28.1 and $30.6 \mathrm{C}$ ). Incubation temperature also affects size of hatchlings in Chelydra serpentina (Brooks et al., 1991; Morris et al., 1983; Packard et al., 1980; Ryan, 1990) and Chrysemys picta (Gutzke et al., 1987; but see Packard et al., 1989). Turtle embryos incubate longer at cooler temperatures and have more time to absorb their yolk and grow. Therefore, they emerge from the egg as larger hatchlings conveying a size advantage (Miller et al., 1987) over hatchlings from warmer eggs that hatch sooner at a smaller size. Incubation temperature also affects the size of hatchling alligators (A. mississippiensis, Deeming and Ferguson, 1989), and crocodiles (Crocodylus niloticus, Hutton, 1987; C. johnstoni and C. porosus, Webb et al., 1987). Thus, this phenomenon is widespread among reptiles.

Reptilian embryos in flexible-shelled eggs frequently hatch at a larger size when incubated in relatively moist environments than when they are incubated in relatively dry environments (for review see Packard and Packard, 1988). This is not true of embryos in rigid-shelled eggs. Their interaction with moist soil may be quite different, in that rigid-shelled eggs have a reduced conductance for water vapor (Ackerman, 1992). The complex nature of the interaction of soil moisture content and potential, soil structure, egg shell structure, and egg metabolism are reviewed by Packard and Packard (1988) and Ackerman (1992). Given the lethal nature of wet substrates for desert tortoise eggs, it is important that the egg shell conductance to liquid water and water vapor be determined 
1own. As incubation prodries out, but probably reisture due to the presence th at the edge of the moister interesting to measure the ntent and moisture tension in desert tortoise nests to water stress to which the d in nature.

incubation condition affect desert tortoises. Large eggs hatchlings. Hatchlings inh temperatures (32.8 and ignificantly smaller than bated at low temperatures C). Incubation temperature of hatchlings in Chelydra ooks et al., 1991; Morris et rd et al., 1980; Ryan, 1990) picta (Gutzke et al., 1987; d et al., 1989). Turtle emlonger at cooler temperamore time to absorb their - Therefore, they emerge larger hatchlings conveyntage (Miller et al., 1987) from warmer eggs that a smaller size. Incubation $o$ affects the size of hatch1. mississippiensis, Deemon, 1989), and crocodiles loticus, Hutton, 1987; C. C. porosus, Webb et al., is phenomenon is wideeptiles.

abryos in flexible-shelled hatch at a larger size when elatively moist environen they are incubated in vironments (for review see ackard, 1988). This is not in rigid-shelled eggs. Their moist soil may be quite t rigid-shelled eggs have a ctance for water vapor 2). The complex nature of f soil moisture content and ucture, egg shell structure, ism are reviewed by Packd (1988) and Ackerman e lethal nature of wet subtortoise eggs, it is imporshell conductance to liqater vapor be determined and that the soil moisture tension curves of soils in nesting sites be determined in order to understand the effects of these factors on hatching success and size of desert tortoise hatchlings. It is quite possible that alterations in the surface structure of desert soils caused by grazing animals and off-road vehicles may alter the water potential isopleths of these soils. Ackerman (1992) provides graphical data that indicate that there are considerable changes in soil moisture potential over short distances in dry sandy soils. Churning up the upper layers of desert soil may cause the drying front to penetrate to a deeper layer of soil and alter the moisture content of desert tortoise nests. Alternatively, it may make the soil more or less permeable to rain water and therefore alter the water potential isopleths for months into the future. If soil structure is changed such that the winter rains are absorbed in a different fashion than normal (i.e., increasing or decreasing runoff), this would affect not only the moisture content of desert tortoise nests months later, but also the soil moisture available to annual and perennial plants which provide shade to nests.

Incubation temperature has an effect on mass of hatchlings and survival of hatchlings up to 120 days after hatching. Mass gain, however, is unaffected by hatching mass. Thus, large eggs produce large hatchlings whose size is also dependent upon incubation temperature, and large hatchlings are still larger 120 days later. All hatchling tortoises grow at similar rates when housed under constant conditions. Therefore, small hatchlings do not catch up in size to their larger siblings. Growth of hatchling snapping turtles, Chelydra serpentina, is affected by incubation temperature (Brooks et al., 1991; Ryan, 1990), as is growth of hatchling alligators (Joanen et al., 1987), and crocodiles (Hutton, 1987; Webb et al., 1987). This effect may be subtle because it is not apparent in all such studies. Large sample sizes are needed to account for the effect of egg size, clutch effects, and individual variation that may mask post-hatching effects of incubation temperature on later growth.

Incubation temperature does not affect temperature selection of hatchling desert tortoises either within a few days or 40 days after hatching. The difference in selected temperature between the hatchlings in 1991 and 1992 may have been due to a seasonal effect. In 1991, the 40 day old hatchlings were tested in the fall as temperatures outside were dropping and daylength was getting shorter. In 1992, hatchlings were tested shortly after hatching during summer. Although hatchlings were held at constant temperature, their photoperiod was maintained at ambient daylength and supplemented by artificial light (L:D 12:12). It is possible that the older hatchlings were adjusting to the reduction in outside photoperiod as they normally would under natural conditions. Incubation temperature does affect thermal selection in crocodiles (Lang, 1987), and Deeming and Ferguson (1989) hypothesize that incubation temperature may affect behavior and temperature selection of alligators. However, snapping turtles acclimated to 15.0 and $25.0 \mathrm{C}$ for several months after hatching had similar selected temperatures in aquatic and terrestrial gradients (Williamson et al., 1989). Therefore, the rules governing this effect are not clear. Incubation temperature does affect post-hatching performance of turtles (Miller et al., 1987) and reproductive behavior and endocrine physiology of lizards (Gutzke and Crews, 1988), and may affect survival of hatchling Aldabra tortoises (Geochelone giganteca, Swingland and Coe, 1979). However, there is no extended effect of incubation condition on posthatching performance and learning ability as measured by righting and feeding responses of snapping turtles (Ryan, 1990). Again this effect is quite complicated and probably depends upon the same factors that are important in studies of post-hatching growth cited above.

\section{Management Implications}

Temperature-dependent sex determination in the desert tortoise and the effects that incubation temperature and water potential of soil have on hatching success, hatchling size, and post-hatching growth have important implications for the management of the desert tortoise. Management strategies should be very conserva- 
tive (Spotila and Standora, 1986). Natural vegetation communities and native soil composition and structure should be preserved or restored. The presence of vegetation alters the quantity of solar radiation absorbed at the soil surface and the transpiration of water from the soil. Desert tortoises lay their eggs in nests under vegetation or in their burrows. Vegetation reduces the temperature range experienced in the soil because radiation absorption is distributed through the height of the vegetation rather than through a thin absorption layer when there is bare soil (Geiger, 1959; Rose, 1966). While we may think of perennial vegetation as being important in this regard, annual plants can have a tremendous effect by providing a blanket of plants that, especially in spring and early in the summer, can change the albedo of the desert. Soil compaction and mixing affect thermal conductivity, heat capacity, thermal diffusivity, and soil structure, thereby affecting heat transfer, soil temperatures, nest temperatures, water infiltration, evaporation rates, and soil moisture potential around desert tortoise eggs.

Additional information is needed on pivotal temperatures for desert tortoise populations in other parts of its range and to determine normal conditions in desert tortoise nests under natural conditions. A very conservative approach to development is warranted until more information is obtained about the natural sex ratio of populations of the desert tortoise in affected areas, the location of successful nesting areas, the thermal and hydric conditions in natural nests, and the effect of these factors on the survival of hatchlings. The chances for long term recovery and survival of desert tortoise populations will be improved by more information on the pivotal temperatures and nesting ecology of these populations and by restoration of the natural vegetation and soil conditions of the desert.

Acknowledgments. - We thank C. Salice, A. Donaldson, and all of the students from Drexel University, San Diego Zoo, University of Wisconsin, and University of Nevada at Las Vegas who helped with this study. J. Moore of the Nature Conservancy provided invaluable support throughout the study. M. Berko- witz, S. Slone, and D. Duncan of the Bureau of Land Management and B. Hardenbrook and C. Tomlinson of the Nevada Department of Wildlife provided technical advice, logistical support, and helping hands. Their dedication and professionalism made this study possible. M. Ewert provided helpful suggestions on experimental design and methodology. R. Ackerman kindly determined soil moisture tensions of our experimental sand. This research was funded by a grant from the Nature Conservancy (contract number GBFO-030191DRX) to Drexel University.

\section{LITERATURE CITED}

ACKERMAN, R. A. 1981 $a$. Growth and gas exchange of embryonic sea turtles (Chelonia, Caretta). Copeia 1981:757-765.

1981b. Oxygen consumption by sea turtle (Chelonia, Caretta) eggs during development. Physiol. Zool. 54:316-324.

1992. Physical factors affecting the water exchange of buried reptile eggs. Pp. 193-211. In D. C. Deeming and M. Ferguson (Eds.), Egg Incubation: Its Effects on Embryonic Development in Birds and Reptiles. Cambridge University Press, New York.

Alho, C., T. Danni, and L. Padua. 1985. Temperature-dependent sex determination in Podoc nemis expansa (Testudinata: Pelomedusidae). Biotropica 17:75-78.

Allen, N. E., O. T. Oftedal, D. J. BaEk, and D WERNER. 1991. Nutritional studies with the green iguana. Proc. Eighth Doctor Scholl's Conf. on the Nutrition of Captive Wild Animals: 73-81. Lincoln Park Zool. Soc., Chicago, Illinois.

Brooks, R. J., M. L. Bobyn, D. A. Galbraith, J. A LAYFIELD, AND E. G. NANCEKIVELL. 1991. Maternal and environmental influences on growth and survival of embryonic and hatchling snapping turtles (Chelydra serpentina). Can. J. Zool. 69:26672676.

BULL, J. J. 1980. Sex determination in reptiles. Quart. Rev. Biol. 55:3-21.

1983. Evolution of Sex Determining Mechanisms. Benjamin/Cummings, Menlo Park, California.

Bull, J. J., R. C. Vogt, AND M. G. Bulmer. $1982 a$ Heritability of sex ratio in turtles with environmental sex determination. Evolution 36:333-341.

BulL, J. J., R. C. Vogt, AND C. J. MCCoy. $1982 b$ Sex determining temperatures in turtles: A geographic comparison. Evolution 36:326-332.

DEEming, D. C., AND M. W. J. Ferguson. 1989 The mechanism of temperature dependent sex determination in crocodilians: A hypothesis. Amer. Zool. 29:973-985.

Ewert, M. A., AND J. M. Legler. 1978. Hormonal induction of oviposition in turtles. Herpetologica 34:314-318.

Ewert, M. A., and C. E. Nelson. 1991. Sex determination in turtles: Diverse patterns and some possible adaptive values. Copeia 1991:50-69.

Ewert, M. A., D. R. JaCKSON, AND C. E. NELSON 1994. Patterns of temperature-dependent sex determination in turtles. J. Exp. Zool.:In press. 
D. Duncan of the Bureau of Land B. Hardenbrook and C. Tomlinson rartment of Wildlife provided techitical support, and helping hands. nd professionalism made this study 't provided helpful suggestions on gn and methodology. R. Ackerman i soil moisture tensions of our ex[his research was funded by a grant - Conservancy (contract number $\mathrm{X})$ to Drexel University.

\section{'ERATURE Cited}

1981a. Growth and gas exchange za turtles (Chelonia, Caretta). Co765.

Oxygen consumption by sea turtle etta) eggs during development. $4: 316-324$.

'hysical factors affecting the water iried reptile eggs. Pp. 193-211. In ; and M. Ferguson (Eds.), Egg Inffects on Embryonic Development ptiles. Cambridge University Press,

NNI, AND L. PADUA. 1985. Temdent sex determination in Podoc(Testudinata: Pelomedusidae). Bio'8.

. T. Oftedal, D. J. BAEK, AND D. Nutritional studies with the green Eighth Doctor Scholl's Conf. on the utive Wild Animals: 73-81. Lincoln , Chicago, Illinois.

L. Bobyn, D. A. Galbraith, J. A. E. G. NANCEKIVELL. 1991. Maronmental influences on growth and ryonic and hatchling snapping turserpentina). Can. J. Zool. 69:2667-

Sex determination in reptiles. Quart. -21 .

Evolution of Sex Determining Mechnin/Cummings, Menlo Park, Cali-

VOGT, AND M. G. BULMER. $1982 a$. sex ratio in turtles with environermination. Evolution 36:333-341. VOGT, AND C. J. MCCoY. $1982 b$. ig temperatures in turtles: A georison. Evolution 36:326-332.

AND M. W. J. Ferguson. 1989. a of temperature dependent sex decrocodilians: A hypothesis. Amer. 35.

JD J. M. LEGLER. 1978. Hormonal viposition in turtles. Herpetologica

ND C. E. Nelson. 1991. Sex deturtles: Diverse patterns and some ve values. Copeia 1991:50-69.

. R. JACKSON, AND C. E. NELSON. of temperature-dependent sex deturtles. J. Exp. Zool.:In press.
Geiger, R. 1959. The Climate Near the Ground. Harvard University Press, Cambridge, MA.

GuTZKe, W. H. N., AND D. CREwS. 1988. Embryonic temperature determines adult sexuality in a reptile. Nature 332:832-834.

GuTzKe, W. H. N., AND G. L. Paukstis. 1983. Influence of hydric environment on sexual differentiation of turtles. J. Exp. Zool. 226:467-469.

Gutzke, W. H. N., G. C. PACKard, M. J. PaCKard, AND T. J. BOARDMAN. 1987. Influence of the hydric and thermal environments on eggs and hatchlings of painted turtles (Chrysemys picta). Herpetologica 43:393-404.

HUTTON, J. M. 1987. Incubation temperatures, sex ratios and sex determination in a population of Nile crocodiles (Crocodylus niloticus). J. Zool., Lond. 211:143-155.

JANZEN, F. J. 1992. Heritable variation for sex ratio under environmental sex determination in the common snapping turtle (Chelydra serpentina). Genetics 131:155-161.

JANZEN, F. J., AND G. L. PAuKstis. 1991. A preliminary test of the adaptive significance of environmental sex determination in reptiles. Evolution 45: 435-440.

JoAnen, T., L. MCNEAse, and M. W. J. Ferguson. 1987. The effects of egg incubation temperature on post-hatching growth of American alligators. Pp. 535-538. In G. J. W. Webb, S. C. Manolis, and P. J. Whitehead (Eds.), Wildlife Management: Crocodiles and Alligators. Surrey Beatty and Sons, Sydney, Australia.

LANG, J. W. 1987. Crocodilian thermal selection. Pp. 301-317. In G. J. W. Webb, S. C. Manolis, and P. J. Whitehead (Eds.), Wildlife Management: Crocodiles and Alligators. Surrey Beatty and Sons, Sydney, Australia.

Miller, K., G. C. PaCkard, and M. J. PaCkard. 1987. Hydric conditions during incubation influence locomotor performance of hatchling snapping turtles. J. Exp. Biol. 127:410-412.

Morreale, S. J., G. J. Ruiz, J. R. Spotila, and E. A. STANDORA. 1982. Temperature dependent sex determination: Current practices threaten conservation of sea turtles. Science 216:1245-1247.

Morris, K. A., G. C. PaCKard, T. J. Boardman, G. L. Paukstis, AND M. J. PACKARD. 1983. Effect of the hydric environment on the growth of the embryonic snapping turtle (Chelydra serpentina). Herpetologica 39:272-285.

MORTIMER, J. A. 1992. Marine turtle conservation in Malaysia. Proc. Intl. Conf. Tropical Biodiversity, Kuala Lumpur, Malaysia.

PaCkard, G. C., AND M. J. PaCKard. 1988. The physiological ecology of reptilian eggs and embryos. Pp. 555-573. In C. Gans and R. Huey (Eds.), Biology of the Reptilia, Vol. 16 (B). Alan R. Liss, Inc., New York.

PaCKard, G. C., T. L. Taigen, M. J. PaCKard, AND T. J. BOARDMAN. 1980. Water relations of pliable shelled eggs of common snapping turtles (Chelydra serpentina). Can. J. Zool. 58:1404-1411.

-1981. Changes in masses of eggs of softshell turtles (Trionyx spiniferus) incubated under hy- dric conditions simulating those of natural nests. J. Zool., Lond. 193:81-90.

PaCKard, G. C., M. J. Packard K. Miller, and T. J. BOARDMAN. 1987. Influence of moisture, temperature, and substrate on snapping turtle eggs and embryos. Ecology 68:983-993.

PACKARD, G. C., M. J. PACKARD, AND G. F. BirChARD. 1989. Sexual differentiation and hatching success by painted turtles incubating in different thermal and hydric environments. Herpetologica 45:385-392.

PiEAU, C. 1971. Sur la proportion sexuelle chez les embryons de deux Cheloniens (Testudo graeca L. et Emys orbicularis L.) issus d'oeufs incubes artificielliment. C. R. Acad. Sci., Paris D 272:3071-3074.

- 1972. Effets de la temperature sur le developpement des glandes genitales chez les embryons de deux cheloniens, Emys orbicularis L. et Testudo graeca L. C. R. Acad. Sci., Paris D 274: 719-722.

- 1978. Effets de temperatures d'incubation basses et elevees sur la differenciation sexuelle chez des embryons d'Emys orbicularis L. (Chelonien). C. R. Acad. Sci. Paris D 286:121-124.

Rose, C. W. 1966. Agricultural Physics. Pergamon Press, New York.

Rostal, D. C., J. S. Grumbles, V. A. Lance, AND J. R. SPOTILA. 1994. Non-lethal sexing techniques for hatchling desert tortoises (Gopherus agassizii). Herpetol. Monogr. 8:83-87.

RYAN, K. M. 1990. Effects of egg incubation condition on the post-hatching growth and performance of the snapping turtle, Chelydra serpentina. M S. Thesis, State College of New York, Buffalo, New York.

SoKal, R. R., AND F. J. RohlF. 1981. Biometry, 2nd ed. W. H. Freeman and Co., San Francisco, California.

SPOTILA, J. R. 1972. Role of temperature and water in the ecology of lungless salamanders. Ecol. Monogr. 42:95-125.

Spotila, J. R., E. A. Standora, S. J. Morreale, G. J. RuIZ, AND C. PuCCIA. 1983. Methodology for the study of temperature related phenomena affecting sea turtle eggs. USFWS Endangered Species Report No. 11, USFWS, Albuquerque, New Mexico.

Spotila, J. R., AND E. A. Standora. 1986. Sex determination in the desert tortoise: A conservative management strategy is needed. Herpetologica 42: 67-72.

Spotila, J. R., E. A. Standora, S. J. Morreale, AND G. J. RuIz. 1987. Temperature dependent sex determination in the green turtle (Chelonia mydas): Effects on the sex ratio on a natural nesting beach. Herpetologica 43:74-81.

Spotila, J. R., L. D. Spotila, AND N. F. Kaufer. 1994. Molecular mechanisms of TSD in reptiles: A search for the magic bullet. J. Exp. Zool.:In press.

Standora, E. A., AND J. R. SpOtila. 1985. Temperature dependent sex determination in sea turtles. Copeia 1985:711-722.

Swingland, I. R., AND M. J. CoE. 1979. The natural regulation of giant tortoise populations on Aldabra 
Atoll: Recruitment. Phil. Trans. R. Soc. Lond. B 286:177-188.

VoGT, R. C., AND J. J. BuLl. 1982. Temperature controlled sex-determination in turtles: Ecological and behavioral aspects. Herpetologica 38:156-164.

VoGT, R. C., AND O. Flores-VIllela. 1992. Ef fects of incubation temperature on sex determination in a community of neotropical freshwater turtles in southern Mexico. Herpetologica 48:265270.

WeBb, G. J. W., A. M. Beal, S. C. MANOLIS, AND K E. DEMPSEY. 1987. The effects of incubation temperature on sex determination and embryonic development rate in Crocodylus johnstoni and $C$. porosus. Pp. 507-531. In G. J. W. Webb, S. C. Manolis, and P. J. Whitehead (Eds.), Wildlife Management: Crocodiles and Alligators. Surrey Beatty and Sons, Sydney, Australia.

WibBels, T., Y. A. MorRIS, D. W. OWENS, G. A. Dienberg, J. NoellK, J. K. Leong, R. E. King, AND R. M. MILLAN. 1989. Predicted se ratios from the international Kemp's Ridley sea turtle head start research project. Pp. 77-81. In C. W.
Caillouet, Jr., and A. M. Landry, Jr. (Eds.), Proceedings of the First International Symposium on Kemp's Ridley Sea Turtle Biology, Conservation and Management. Texas A\&M University, TAMU. SU-89-105.

WibBels, T., J. J. Bull, AND D. CRews. $1991 a$. Chronology and morphology of temperature-dependent sex determination. J. Exp. Zool. 260:371381

Wibbels, T., F. C. Killebrew, and D. Crews. 1991b. Sex determination in Cagle's map turtle: Implications for evolution, development, and conservation. Can. J. Zool. 69:2693-2696.

WILliamson, L. U., J. R. SPOTIla, AND E. A. STANDORA. 1989. Growth, selected temperature, and CTM of young snapping turtles, Chelydra serpentina. J. Therm. Biol. 14:33-39.

YNTEMA, C. L. 1976. Effects of incubation temperature on sexual differentiation in the turtle, Chelydra serpentina. J. Morphol. 150:453-462.

Accepted: 6 March 1994 Associate Editor: James Spotila

Herpetological Monographs, 8, 1994, 116-124

(C) 1994 by The Herpetologists' League, Inc.

\title{
STUDIES ON THE CHEMISTRY AND SOCIAL SIGNIFICANCE OF CHIN GLAND SECRETIONS IN THE DESERT TORTOISE, GOPHERUS AGASSIZII
}

\author{
Allison C. Alberts, David C. Rostal, and Valentine A. Lance \\ Center for Reproduction of Endangered Species, Zoological Society of San Diego \\ P.O. Box 551, San Diego, CA 92112, USA
}

\begin{abstract}
The chemical structure and biological functions of chin gland secretions were examined in a group of captive desert tortoises, Gopherus agassizii, housed at the Desert Tortoise Conservation Center near Las Vegas, Nevada. Monthly measurements of the chin glands of 20 adult males were made over one year. Gland volume varied seasonally, reaching a maximum in late summer. The chin glands of socially dominant males tended to be larger than those of socially subordinate males. Among all males, there was a positive correlation larger than those of socially levels and size of the chin glands. Behavioral a positive correlation between plasma testosterone discriminate the that chin gland secretions may functions of familiar males from those of unfamiliar males, suggesting gland secretions revealed may function in conspecific recognition. Electrophoretic studies of chin 115,000 Daltons. differences existed in the number and patterns among males were very similar, slight individual (n) molecular weight protein components.
\end{abstract}

Key words: Chemical signals; Chin glands; Desert tortoise; Gopherus agassizii; Proteins

TORTOISEs in the genus Gopherus are characterized by two paired integumentary chin, or mental, glands that occur below the mandibles (Smith and Brown, 1948). Histochemical analyses of the chin glands of G. agassizii and G. berlandieri indicate that they are multilobed holocrine structures which open to the exterior through short ducts (Winokur and Legler, 1975). Gas and thin layer chromatographic analyses of chin gland secretions reveal the presence of saturated and unsaturated free fatty acids, phospholipids, triglycerides, and steroids (Rose, 1970; Rose et al., 1969). 